\title{
Plant Biomass, Primary Production and Mineral Cycling of a Mixed Oak Forest in Linnebjer, Sweden
}

\author{
Folke 0. Andersson \\ Department of Ecology, Swedish University of Agricultural Sciences, Uppsala, Sweden \\ Email: folke.andersson@slu.se
}

Received 3 August 2014; revised 17 September 2014; accepted 6 October 2014

Copyright (C) 2014 by author and Scientific Research Publishing Inc.

This work is licensed under the Creative Commons Attribution International License (CC BY).

http://creativecommons.org/licenses/by/4.0/

(c) (i) Open Access

\begin{abstract}
Plant biomass, primary production and mineral cycling were studied in a mixed deciduous forest (Quercus robur L., Tilia cordata L. and Corylus avellana L.) in southern Sweden. Plant biomass amount above and below ground was 201 and $37 \mathrm{t} \cdot \mathrm{ha}^{-1}$, respectively. Primary production above and below ground was an estimated 13.3 and $2.3 \mathrm{t} \cdot \mathrm{ha}^{-1}$, respectively. Carbon was the dominant element in the forest ecosystem, comprising $133 \mathrm{t} \cdot \mathrm{ha}^{-1}$. Other major elements were: $\mathrm{N}>\mathrm{Ca}>\mathrm{K}>$ $\mathrm{Si}>\mathrm{Mg}>\mathrm{S}>\mathrm{Mn}>\mathrm{P}>\mathrm{Fe}$ and Na (range 1123 to $18 \mathrm{~kg} \cdot \mathrm{ha}^{-1}$ ), followed by some trace elements. Yearly litterfall restored 6.0 t.ha- $\mathrm{h}^{-1}$ organic matter or $2.3 \mathrm{t} \cdot \mathrm{ha}^{-1}$ carbon. Approximately $45 \%$ decomposed and returned to the soil during the year. Monitoring of other elements revealed that the ecosystem received inputs through dry and wet deposition, in particular $34.4 \mathrm{~kg} \cdot \mathrm{ha}^{-1} \mathrm{~S}$ and 9.4 $\mathrm{kg}^{-h^{-1}}$ of $\mathrm{N}$ yearly as throughfall. Determination of yearly biomass increase showed that the oak forest ecosystem was still in an aggradation or accumulation phase.
\end{abstract}

\section{Keywords}

Plant Biomass, Primary Production, Litterfall, Deposition, Cycling of C, N, P, K, S

\section{Introduction}

Over the years, the Linnebjer nature reserve, which lies $7 \mathrm{~km} \mathrm{NE}$ of the city of Lund in southern Sweden, has been the subject of detailed investigations of its history, vegetation, organic matter, plant biomass, primary production, water profile, soil physics and soil chemistry. The studies on biomass and primary production led to the development of methods which were later used in Sweden and the Nordic countries. The methods used to determine plant biomass and production and the related results are described in Andersson (1970c) and Reichle 
(1981). However, the studies of the mixed deciduous forest in the reserve also included mineral cycling performed in the early 1970s, the results of which were never satisfactorily published. Therefore they are not available in the scientific literature, but are still valid, in demand and are hence presented in this paper.

The results can be applied in monitoring changes in tree biomass and production, as well as cycling of elements over time. It is also important to have information on the distribution of elements in the stand in order to determine temporal changes in air pollution, especially sulfur and nitrogen deposition.

This paper presents the results obtained to date on mineral cycling in the Linnebjer mixed forest. It includes a summary of biomass and primary production by the tree and field layers as essential background and important functional fractions such as litterfall and deposition, as well as data on their contents of elements. The cycling is discussed using a simple model.

\section{The Mixed Forest}

The dominant vegetation in the Linnebjer nature reserve is mixed deciduous forest. Part of the reserve was used as a special area for detailed investigations (Figure 1 and Figure 2). A full description of the vegetation during the study period is given in Andersson (1970b). In brief, the forest has a number of layers: tree layer $>15 \mathrm{~m}$, upper shrub layer $2-15 \mathrm{~m}$, lower shrub layer $<2 \mathrm{~m}$ and field and bottom layers. The tree layer is dominated by Quercus robur and Tilia cordata and the upper shrub layer by Corylus avellana. The field layer shows seasonal changes, with Anemone nemorosa dominating in spring and Oxalis acetosella in summer. The bottom layer is weakly developed.

\section{Element Cycling Model}

Cycling of elements was assessed using a model developed by Nihlgård (1972) (Figure 3). The analysis was limited to the above-ground parts, as root production and the release of nutrients from the root litter and leaching of elements from the soil were not estimated. However, root biomass was measured. In determining the dynamics of organic matter in a forest, the above-ground yearly net primary production (P) the yearly litterfall (L) and the decomposition rate $(\mathrm{k})$ are the most important factors. Understanding element cycling requires information on the amounts of elements in the primary plant production, the biomass increase $(\Delta \mathrm{B})$, yearly litterfall $(\mathrm{L})$, surface litter (SL) and the canopy-leached fraction (CL = the difference between total through fall and incoming rainfall).

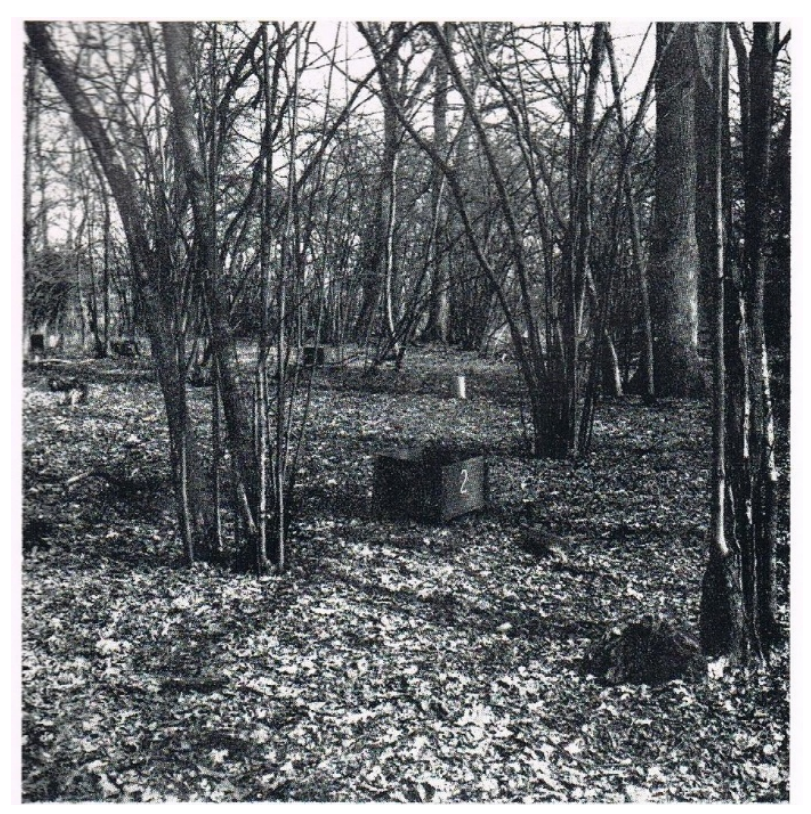

Figure 1. Photo of the oak forest with Quercus robur and Corylus avellana also showing litter traps and a rain gauge. Photo author May 1969. 


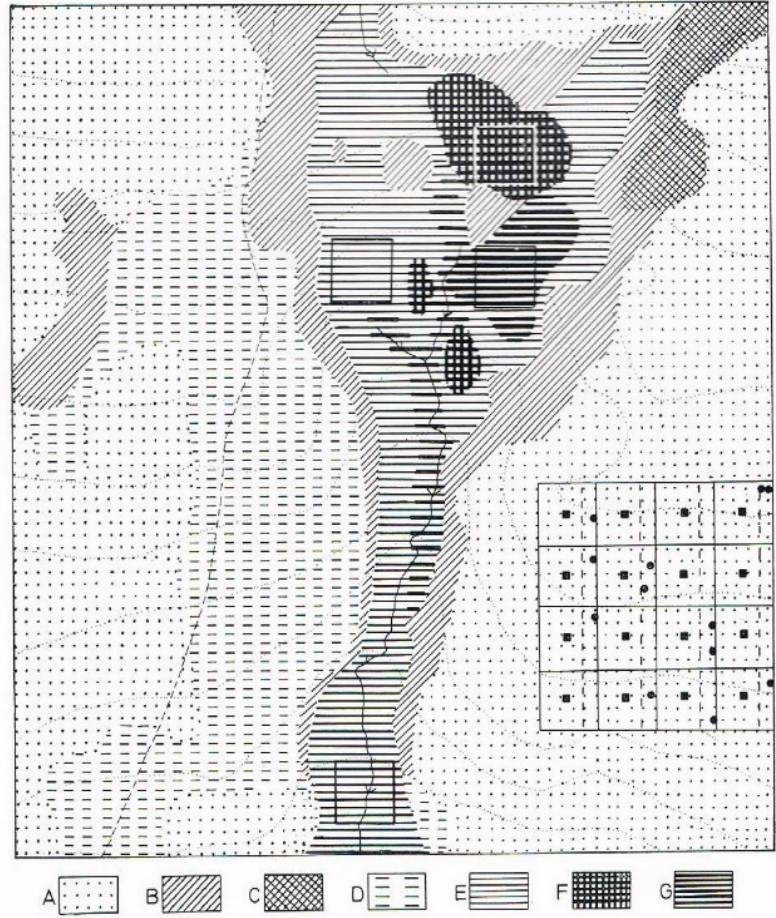

Figure 2. Map of the Special area showing ecosystems and sample areas. Key: A. Quercus robur-Oxalis acerosella ecosystem; B. Quercus robur-Geumrivale ecosystem; C = Quercusrobur-Athyriumfilix-femina ecosystem, D = Clearing phase of ecosystem A and B; E = Filipendula ulmaria ecosystem; F = Carex flacca ecosystem and $\mathrm{G}=$ Carex caespitose ecosystem. In the sample area for ecosystem A the situation of 16 litter traps and 12 rain gauges are shown.

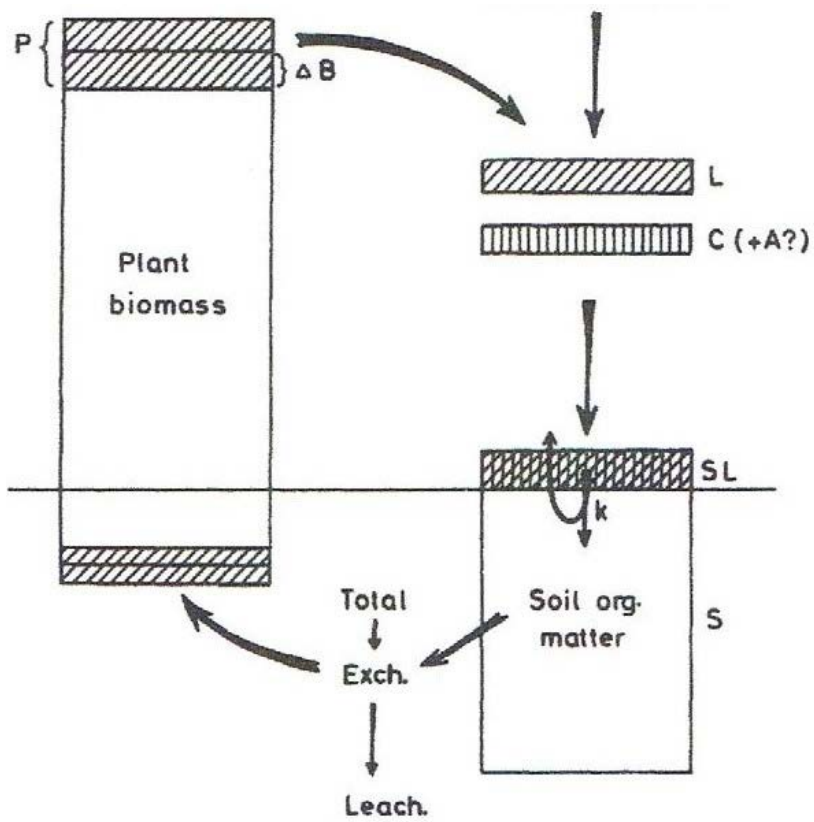

Figure 3. Schematic model of the turnover of organic matter and mineral cycling. For abbreviations see text. 


\section{Methods}

\subsection{Tree Biomass and Production}

A detailed description of the methods developed and applied to the tree layer and the results obtained are provided in Andersson (1970c) and Nihlgård (1972). Therefore, only a summary is given here. The estimates of tree biomass and production were based on allometric regressions, using the relationship between destructive and non-destructive measurements. The estimation procedure comprised four basic steps:

- Stand analyses of non-destructive measurements-tree height and diameter.

- Destructive measurements of sample trees: stem sections or discs, branches, twigs and roots-diameter, age.

- Application of the stand data to the regressions of the sample trees obtained in (2).

- Additional observations on e.g. litterfall.

The above-ground biomass and production of trees were studied specifically for 11 Quercus robur, 6 Tilia and Sorbus and 18 Corylus. Studies of the below-ground parts with roots were limited to three individuals of each tree species. The main root biomass fraction, comprising roots $>0.5 \mathrm{~cm}$ in diameter, was collected around the tree. The fine root biomass $(<0.5 \mathrm{~cm}$ diameter) was collected in 10 pits measuring $50 \mathrm{~cm} \times 50 \mathrm{~cm} \times 60 \mathrm{~cm}$ excavated along a transect at regular intervals of $2 \mathrm{~m}$.

\subsection{Field Layer}

The above-ground biomass of the field layer was sampled on occasions corresponding to the maximum development of the seasonal species. Total primary production was calculated by adding the maximum values obtained for the different species investigated. These were sampled in 16 squares $(50 \mathrm{~cm} \times 50 \mathrm{~cm})$ selected at random on each sampling occasion. Below-ground parts were collected within the same squares.

\subsection{Litter and Litterfall}

Litterfall was collected in 16 litter traps $(50 \mathrm{~cm} \times 50 \mathrm{~cm} \times 30 \mathrm{~cm})$ laid out in a systematic way. The trap sides were made of wooden boards and the base of nylon netting and they were placed $20 \mathrm{~cm}$ above the ground surface. Coarse litter such as twigs and pieces longer than $0.5 \mathrm{~m}$ were collected yearly in a $20 \mathrm{~cm} \times 20 \mathrm{~cm}$ square sampling area. Random samples of surface litter were taken twice a year, before and after leaf shedding, in 16 squares measuring $50 \mathrm{~cm} \times 50 \mathrm{~cm}$.

\subsection{Deposition}

In connection with an investigation of element cycling in the oak forest (Andersson 1970b), rain samples were collected and subjected to chemical analysis in order to determine the deposition of sulfur and nitrogen, as well as other incoming nutrients. These samples were collected as through fall in a special area of the forest (Figure 1 and Figure 2).

\subsection{Collectors and Collection}

The incoming rainfall was measured at a nearby farm $300 \mathrm{~m}$ from the throughfall sampling area. A rain gauge of type SMHI with a diameter of $16 \mathrm{~cm}$ and fitted with a wind shelter was used (SMHI 1958), placed with the opening $1.5 \mathrm{~m}$ above ground. A comparison with data obtained with other gauges used in the forest (see below) showed that the results was usually within the reported range of observations (Nihlgård 1970), although occasionally they were $3 \%$ lower.

The throughfall was collected in 12 gauges randomly spread in a forested area of $1600 \mathrm{~m}^{2}$. The gauges consisted of 1-L polythene bottles with a plastic funnel with diameter $15 \mathrm{~cm}$ fitted in the lid. A filter of inert glass wool was placed in the bottom of the funnel to prevent material entering the bottle. To stabilise the gauges, they were placed on the ground inside metal tubes (diameter $16 \mathrm{~cm}$ ). The top of the gauges was $30 \mathrm{~cm}$ above the ground.

The rain gauges were emptied after each rain event between December 2, 1966 and November 2, 1967. The volume was measured and the $\mathrm{pH}$ was determined in order to identify samples with impurities. The bottles were stored cool and then brought to the laboratory on 15 occasions during the measurement period for chemical analyses. 


\subsection{Chemical Analyses of Water}

On arrival at the laboratory, the samples were pooled into four composite samples and kept $\operatorname{cool}\left(+4^{\circ} \mathrm{C}\right)$. Analyses were carried out within one month as follows:

$p H$ was determined with a $\mathrm{pH}$-meter, type Beckman $\mathrm{N}-2$ (accuracy \pm 0.02 ). In calculating average $\mathrm{pH}$, the $\mathrm{pH}$ values were first transformed to concentration of hydrogen ions and the average was converted back to $\mathrm{pH}$ (cf. Barrett \& Brodin 1955).

Further analyses were performed on filtered water. The cations $\mathrm{Na}, \mathrm{K}, \mathrm{Ca}, \mathrm{Mg}$, Fe and $\mathrm{Mn}$ were determined on a Perkin-Elmer Atomic Absorption Spectrophotometer, with analytical error normally 1\%, estimated from the standard curves.

Chloride concentration was determined with a mercurimetric method using diphenylcarbazon as an indicator (Clarke, 1950). The accuracy was $\pm 5 \%$, calculated as standard deviation of duplicate analyses (Nihlgård, 1970). Sulphate concentration was determined with a turbidimetric method using $\mathrm{BaCl}_{2}$ and an acid seed solution (Chesnin Yien, 1950; Rossum \& Villarez, 1961). The accuracy $\pm 7 \%$, calculated as for chloride. Phosphate concentration was determined with a colorimetric method after reduction with ascorbic acid and addition of K-antimonyltartrate plus ammonium molydate (Murphy \& Riley, 1962). The accuracy was $\pm 7 \%$, calculated as above. Nitrate concentration was tentatively determined using a colorimetric method (accuracy $\pm 10 \%$, calculated as above), with alpha-naphthylamine and sulphanilic acid after addition of $\mathrm{HAc}, \mathrm{BaSO}_{4}$ and $\mathrm{MnSO}_{4}$ (cf Bray, 1945, Method 1, Procedure 1). Ammonia concentration was determined tentatively using Nessler's regent after addition of sodium potassium tartrate (accuracy $\pm 7 \%$, calculated as above). Total nitrogen concentration was analysed by a macro-Kjeldahl distillation method (Karlgren, 1962). The accuracy was $\pm 6 \%$, calculated as for chloride.

\subsection{Soil Sampling and Chemical Analyses}

The soil sampling procedure and the methods applied for determination of exchangeable and total amounts of elements are described in full in Andersson, 1970b (pp. 141-146). Statistical analyses are also described in the same publication.

\subsection{Statistics}

Results are generally presented as means. Percentage errors are given at $95 \%$ confidence limit as percentage of the mean. Andersson (1970b) discuss different statistical aspects of errors in sampling and computations.

\section{Results}

\subsection{Biomass and Production of the Tree, Shrub and Field Layers}

Biomass and primary production are essential as carrier substances of the elements treated in this paper, so the results presented by Andersson (1970b) for the Linnebjer nature reserve are summarised here. Tree biomass (B) of the mixed forest was estimated to be $238 \mathrm{t} \cdot \mathrm{ha}^{-1}$, with 201 aboveground and $38 \mathrm{t} \cdot \mathrm{ha}^{-1}$ belowground (Table 1).

Yearly above-ground primary production (PP) was estimated to be $13.3 \mathrm{t}^{\cdot} \mathrm{ha}^{-1} \cdot \mathrm{yr}^{-1}$. This included plant losses by death and shedding (L), which amounted to $0.7 \mathrm{t}^{-\mathrm{ha}^{-1}} \cdot \mathrm{yr}^{-1}$, and plant losses by consumers $(\mathrm{G})$, which amounted to $0.4 \mathrm{t}^{\mathrm{hah}} \mathrm{h}^{-1} \cdot \mathrm{yr}^{-1}$. The below-ground production of tree and understory layers was estimated to be

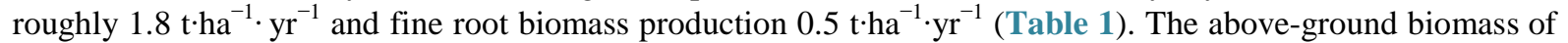
the field layer was $0.06-0.2 \mathrm{t}^{-h^{-1}}$ and its below-ground biomass was $2.4-2.6 \mathrm{t}^{\mathrm{h}} \mathrm{ha}^{-1}$ (Table 1 and Table 2).

\subsection{Element Amounts and Their Distribution in Biomass and in Production Fractions of the Tree, Shrub and Field Layers}

The carbon content in the above-ground fraction of trees and shrubs was $114 \mathrm{t}_{\mathrm{h}} \mathrm{h}^{-1}$ and that in the below-ground fraction was $19 \mathrm{t}^{\mathrm{a}} \mathrm{a}^{-1}$. A factor of 2 is often accepted for conversion of carbon to biomass. The nitrogen content was $0.81 \mathrm{t} \cdot \mathrm{ha}^{-1}$ in above-ground tree and shrub biomass including also the field layer and $0.32 \mathrm{t} \cdot \mathrm{ha} \mathrm{H}^{-1}$ in belowground biomass. For the finer fractions, a higher relative content was found. The field layer above and below ground contained minor amounts of elements (Table 2 and Table 3). 
Table 1. Plant biomass and yearly production ( $\left(\cdot \mathrm{ha}^{-1}\right.$ dry weight at $\left.85^{\circ} \mathrm{C}\right)$ of the tree layer in a mixed woodland with Quercus robur and Corylus avellana. Linnebjer, Sweden.

\begin{tabular}{|c|c|c|c|}
\hline & \multicolumn{2}{|c|}{ Biomass } & Production \\
\hline Overstory trees & 155 & - & 6.3 \\
\hline Quercus robur & - & 15.8 & - \\
\hline Understory trees & 29 & & 2.1 \\
\hline Tilia cordata & - & 25.5 & - \\
\hline Sorbus aucubaria & - & 1.6 & - \\
\hline Prunus avium & - & 0.6 & - \\
\hline Ulmus glabra & - & 0.6 & - \\
\hline Populus tremula & & 0.2 & - \\
\hline Shrubs & 17 & & 3.0 \\
\hline Corylus avellana & - & & \\
\hline Field layer & 0.2 & & 0.8 \\
\hline Plant losses by death and shedding (L) & - & & 0.7 \\
\hline Plant losses by consumers (G) & - & & 0.4 \\
\hline Total above ground & 201 & & 13.3 \\
\hline \multicolumn{4}{|l|}{$\underline{\text { Root }}$} \\
\hline \multicolumn{4}{|l|}{ Main root biomass $>0.5 \mathrm{~cm} \varnothing$} \\
\hline Quercus robur & 27 & & 0.9 \\
\hline \multicolumn{4}{|l|}{ Understory trees } \\
\hline Corylus avellana & 7 & & 0.9 \\
\hline Fine root biomass $<0.5 \mathrm{~cm} \varnothing$ - & 3 & & 0.5 \\
\hline \multicolumn{4}{|l|}{ Trees and shrubs } \\
\hline Total below-ground & 37 & & 2.3 \\
\hline TOTAL & 238 & & 15.6 \\
\hline
\end{tabular}

Table 2. Plant biomass and yearly production (t.ha ${ }^{-1}$ dry weight at $85^{\circ} \mathrm{C}$ ) of the tree layer in a mixed woodland with Quercus robur and Corylus avellana. Linnebjer, Sweden.

\begin{tabular}{|c|c|c|c|c|c|c|c|c|c|c|c|c|c|}
\hline & Organicmatter & $\mathrm{C}$ & $\mathrm{N}$ & $\mathrm{C} / \mathrm{N}$ & $\mathrm{Na}$ & $\mathrm{K}$ & $\mathrm{Ca}$ & $\mathrm{Mg}$ & Mn & $\mathrm{Fe}$ & Si & $\mathrm{P}$ & $\mathrm{S}$ \\
\hline & \multicolumn{3}{|c|}{$\mathrm{kg} \cdot \mathrm{ha}^{-1}$} & ratio & \multicolumn{9}{|c|}{$g \cdot h a^{-1}$} \\
\hline \multicolumn{14}{|l|}{ Above-ground } \\
\hline Convallaria majalis & 10 & 4.2 & 0.21 & 20 & 0.419 & 18.8 & 119 & 43 & 12 & 1.8 & 0.8 & 16.2 & 16 \\
\hline Oxalis acetosella & 45 & 18.7 & 1.73 & 14 & 5.170 & 126.7 & 343 & 148 & 49 & 9.4 & 5.3 & 96.8 & 121 \\
\hline Other species & 15 & 7.3 & 0.53 & 14 & 2.760 & 33.4 & 102 & 56 & 12 & 4.3 & 2.1 & 37.7 & 29 \\
\hline Total above-ground $\mathrm{kg} \cdot \mathrm{ha}^{-1}$ & 70 & 30.2 & 2.11 & & 0.008 & 0.18 & 0.56 & 0.25 & 0.07 & 0.02 & 0.01 & 0.15 & 0.17 \\
\hline \multicolumn{14}{|l|}{ Below-ground } \\
\hline Anemone nemorosa & 2320 & 1035 & 49.0 & & 821.4 & 2812 & 6790 & 4400 & 3820 & 3320 & 1550 & 3366 & 4990 \\
\hline Other species & 290 & 123 & 6.5 & & 104.0 & 238 & 1170 & 490 & 43 & 380 & 580 & 284 & 580 \\
\hline Total below-ground $\mathrm{kg} \cdot \mathrm{ha}^{-1}$ & 2610 & 1158 & 55.5 & 19 & 0.93 & 3.05 & 7.96 & 4.89 & 4.25 & 3.70 & 2.13 & 3.65 & 5.57 \\
\hline $\begin{array}{l}\text { SUM OF ABOVE-AND } \\
\text { BELOW-GROUND }\end{array}$ & 2680 & 1188 & 57.6 & & 0.94 & 3.23 & 8.52 & 5.14 & 4.32 & 3.72 & 2.14 & 3.80 & 5.74 \\
\hline
\end{tabular}

In order to set the concentrations of elements and their distribution in the biomass fractions in the forest into perspective, a comparison was using beech forests along a fertility gradient in the same region (Table 4). The fertility can be described by the degree of base saturation of the soil. The Linnebjer forest had a similar degree (around 20\%) as surrounding Lamium-type beech forests (Nihlgård \& Lindgren 1977). Mercurialis-type beech forests have a high soil base saturation and Deschampsia-type a low soil base saturation. The Deschampsia-type forests also have a lower carbon content than nutrient-richer forests, while $\mathrm{K}$, $\mathrm{Ca}$ and $\mathrm{Mg}$ are related to availabi- 
Table 3. Mineral content ( $\mathrm{t} \cdot \mathrm{ha}^{-1}$ dry weight at $85^{\circ} \mathrm{C}$ ) of a mixed forest of Quercus robur and Corylus avellana in Linnebjer, Sweden.

\begin{tabular}{|c|c|c|c|c|c|c|c|c|c|c|c|c|c|c|c|c|}
\hline Fraction & $\mathrm{C}$ & $\mathrm{N}$ & $\mathrm{C} / \mathrm{N}$ & $\mathrm{Na}$ & $\mathrm{K}$ & $\mathrm{Ca}$ & $\mathrm{Mg}$ & $\mathrm{Mn}$ & $\mathrm{P}$ & $\mathrm{S}$ & $\mathrm{Fe}$ & $\mathrm{Si}$ & $\mathrm{Pb}$ & $\mathrm{Zn}$ & $\mathrm{Cu}$ & $\mathrm{Ni}$ \\
\hline & \multicolumn{2}{|c|}{ tha $^{-1}$} & ratio & \multicolumn{13}{|c|}{$\mathrm{kg} \mathrm{ha}^{-1}$} \\
\hline \multicolumn{17}{|l|}{$\begin{array}{c}\text { Above-ground } \\
\text { Tree layer }\end{array}$} \\
\hline Stem wood & 75.8 & 0.219 & 346 & 4.8 & 148 & 200 & 25 & 12 & 9.5 & 16.0 & 5.8 & 30.8 & 0.25 & 0.87 & 0.32 & 0.19 \\
\hline Stem bark & 8.3 & 0.104 & 80 & 0.8 & 30 & 247 & 12 & 10 & 4.2 & 9.8 & 2.2 & 21.7 & 0.12 & 0.20 & 0.09 & 0.07 \\
\hline Branches & 27.1 & 0.400 & 68 & 4.3 & 60 & 82 & 40 & 29 & 30.1 & 21.6 & 5.6 & 41.5 & 0.56 & 1.37 & 0.33 & 0.22 \\
\hline Current twigs & 2.8 & 0.081 & 35 & 0.6 & 30 & 30 & 10 & 9 & 5.2 & 5.2 & 1.5 & 16.5 & 0.06 & 0.26 & 0.04 & 0.03 \\
\hline Field layer & 0.03 & 0.002 & 14 & 0.01 & 0.18 & 0.56 & 0.25 & 0.07 & 0.15 & 0.17 & 0.02 & - & - & - & - & - \\
\hline Total above-ground & 114.0 & 0.806 & - & 10.5 & 268 & 559 & 87 & 60 & 49.2 & 52.8 & 15.1 & 110.5 & 0.99 & 2.70 & 0.78 & 0.51 \\
\hline \multicolumn{17}{|l|}{ Below-ground } \\
\hline Tree layer & & & & & & & & & & & & & & & & \\
\hline Roots $>0.5 \mathrm{~cm}$ & 15.8 & 0.230 & 69 & 5.4 & 8 & 142 & 17 & 6 & 12.5 & 20.2 & 16.3 & 111 & 0.09 & 0.36 & 0.13 & 0.11 \\
\hline Roots $<0.5 \mathrm{~cm}$ & 1.6 & 0.031 & 52 & 1.1 & 1 & 22 & 5 & 2 & 1.5 & 4.3 & 3.8 & 52.1 & 0.02 & 0.13 & 0.02 & 0.04 \\
\hline Field layer & 1.2 & 0.056 & 21 & 0.9 & 3 & 8 & 5 & 4 & 3.7 & 5.6 & 3.7 & - & 0.09 & 0.33 & 0.03 & 0.03 \\
\hline Total below-ground & 18.6 & 0.317 & - & 7.4 & 12 & 172 & 27 & 12 & 17.7 & 30.1 & 23.8 & 163.1 & 0.20 & 0.82 & 0.18 & 0.18 \\
\hline $\begin{array}{l}\text { TOTAL ABOVE-AND } \\
\text { BELOW-GROUND }\end{array}$ & 132.6 & 1.123 & - & 17.9 & 280 & 731 & 114 & 72 & 66.9 & 82.1 & 38.9 & 273.6 & 1.19 & 3.52 & 0.96 & 0.69 \\
\hline
\end{tabular}

Table 4. Comparison of the element distribution in the biomass of a mixed forest of Quercus robur and Corylus avellana in Linnebjer, Sweden, with that in neighboring beech forests along a fertility gradient in southernmost province in Sweden.

\begin{tabular}{|c|c|c|c|c|c|c|c|c|c|c|c|c|c|}
\hline \multirow{2}{*}{\multicolumn{2}{|c|}{ Forest type }} & \multirow{2}{*}{$\begin{array}{c}\text { Base } \\
\text { saturation \% }\end{array}$} & \multirow{2}{*}{$\begin{array}{l}\text { Basal } \\
\text { area } \mathrm{m}^{2} \cdot \mathrm{ha}^{-1}\end{array}$} & \multirow{2}{*}{$\begin{array}{c}\mathrm{C} \\
\mathrm{t} \cdot \mathrm{ha}^{-1}\end{array}$} & $\mathrm{~N}$ & $\mathrm{P}$ & $\mathrm{Na}$ & $\mathrm{K}$ & $\mathrm{Ca}$ & $\mathrm{Mg}$ & $\mathrm{Mn}$ & $\mathrm{Fe}$ & $\mathrm{S}$ \\
\hline & & & & & \multicolumn{9}{|c|}{$\mathrm{kg} \cdot \mathrm{ha}^{-1}$} \\
\hline Oak & Oxalis & 21 & 31 & 114 & 81 & 49 & 11 & 268 & 559 & 87 & 60 & 15 & 53 \\
\hline \multirow[t]{3}{*}{ Beech } & Mercurialis & 60 & 31 & 156 & 83 & 55 & 24 & 465 & 924 & 121 & 2 & 6 & 59 \\
\hline & Lamium & 22 & 31 & 159 & 106 & 85 & 32 & 460 & 663 & 105 & 111 & 15 & 68 \\
\hline & Deschampsia & 12 & 30 & 119 & 64 & 65 & 17 & 318 & 478 & 85 & 29 & 5 & 65 \\
\hline
\end{tabular}

From: Oak (Andersson, 1970b); Beech (Nihlgård \& Lindgren 1977).

lity in the form of exchangeable amounts in soil and in total biomass. Other elements such as $\mathrm{P}$, Mn and Fe are dependent on the degree of solubility, which is regulated by soil $\mathrm{pH}$. Sulfur to some extent reflects atmospheric deposition.

\subsection{Amounts of Elements in Litterfall and Surface Litter}

In order to analyse the circulation of elements, data on yearly litterfall $(\mathrm{L})$ and the dynamics of the surface litter (SL) were used (Table 5).

The nitrogen content in the annual litterfall was $69 \mathrm{~kg} \cdot \mathrm{ha}^{-1}$. The other elements were present in the following descending order: $\mathrm{Ca}, \mathrm{Si}, \mathrm{Mg}, \mathrm{K}, \mathrm{S}, \mathrm{Mn}, \mathrm{P}, \mathrm{Fe}$ and $\mathrm{Na}$, in amounts ranging from 41 to $0.9 \mathrm{~kg} \cdot \mathrm{ha}^{-1} \cdot \mathrm{yr}^{-1}$. The surface litter comprised $6.0 \mathrm{t} \cdot \mathrm{ha}^{-1}$ organic matter, or $2.8 \mathrm{t} \cdot \mathrm{ha}^{-1}$ of carbon with a nitrogen content of $107 \mathrm{~kg} \cdot \mathrm{ha}^{-1}$. The other elements occurred in the following descending order: $\mathrm{Ca}, \mathrm{Si}, \mathrm{S}, \mathrm{Mg}, \mathrm{Mn}, \mathrm{K}, \mathrm{P}, \mathrm{Fe}$ and $\mathrm{Na}$, in amounts ranging from 59 to $0.8 \mathrm{~kg} \cdot \mathrm{ha}^{-1}$.

Some readily mobile elements, such as $\mathrm{K}$ and $\mathrm{Na}$, had a decomposition rate (k-value) of approx. 50\%, indicating that half the litterfall amount was turned over during one year. Other elements such as Si had a slow turnover rate of $14 \%$, while the rest had intermediate values.

\subsection{Amount of Elements in Precipitation, Throughfall and Interception}

Input of elements was the result of precipitation measured in the open field (In), and of not measured dry deposited, aerosols (A) (Table 6 and see Figure 1).

Content of elements $\left(\mathrm{kg} \cdot \mathrm{ha}^{-1}\right)$ in incoming precipitation (In), throughfall (T) and interception (Diff = canopy leached fraction) in a mixed forest of Quercus robur and Corylus avellana in Linnebjer, Sweden (Table 6).

Through fall (T) was measured and the difference between In and $\mathrm{T}$ (Diff) indicated leached (positive values) 
Table 5. Content of organic matter and elements in litterfall (L) and surface litter (SL) and decomposition factor k (L/L + SL) of a mixed forest of Quercus robur and Corylus avellana in Linnebjer, Sweden, April 1966-March 1967.

\begin{tabular}{|c|c|c|c|c|c|c|c|c|c|c|c|c|c|}
\hline Period & Fraction & $\begin{array}{l}\text { Org. } \\
\text { matter }\end{array}$ & $\mathrm{C}$ & $\mathrm{N}$ & $\mathrm{Na}$ & $\mathrm{K}$ & $\mathrm{Ca}$ & $\mathrm{Mg}$ & $\mathrm{Mn}$ & $\mathrm{Fe}$ & $\mathrm{Si}$ & $\mathrm{P}$ & $\mathrm{S}$ \\
\hline & & \multicolumn{12}{|c|}{$\mathrm{kg} \cdot \mathrm{ha}^{-1}$} \\
\hline \multirow{4}{*}{$\begin{array}{l}\text { April 66- } \\
\text { June } 66\end{array}$} & Twigs & 245 & 120 & 3.72 & 0.06 & 0.34 & 1.88 & 0.27 & 0.18 & 0.04 & 0.45 & 0.16 & 0.23 \\
\hline & Leaves & 53 & 26 & 1.71 & 0.01 & 0.15 & 0.43 & 0.12 & 0.04 & 0.01 & 0.16 & 0.06 & 0.07 \\
\hline & Budscales & 310 & 152 & 6.17 & 0.04 & 0.52 & 2.79 & 0.60 & 0.26 & 0.07 & 0.70 & 0.36 & 0.27 \\
\hline & Misc. & 8 & 4 & 0.08 & 0 & 0.02 & 0.04 & 0.02 & 0.01 & 0 & 0.02 & 0.01 & 0.02 \\
\hline \multirow{4}{*}{$\begin{array}{l}\text { July 66- } \\
\text { Sept. } 66\end{array}$} & Twigs & 238 & 117 & 2.52 & 0.06 & 0.34 & 2.06 & 0.20 & 0.14 & 0.09 & 0.57 & 0.13 & 0.22 \\
\hline & Leaves & 212 & 104 & 4.37 & 0.08 & 0.82 & 1.90 & 0.44 & 0.29 & 0.04 & 0.58 & 0.24 & 0.27 \\
\hline & Budscales & 204 & 100 & 4.06 & 0.03 & 0.79 & 1.83 & 0.39 & 0.17 & 0.05 & 0.48 & 0.24 & 0.18 \\
\hline & Misc. & 174 & 85 & 4.11 & 0.05 & 0.31 & 1.81 & 0.33 & 0.16 & 0.05 & 1.70 & 0.27 & 0.16 \\
\hline \multirow{4}{*}{$\begin{array}{l}\text { Oct. } 66- \\
\text { Nov. } 66\end{array}$} & Twigs & 87 & 43 & 0.85 & 0.02 & 0.13 & 0.65 & 0.08 & 0.06 & 0.03 & 0.17 & 0.04 & 0.07 \\
\hline & Leaves & 1491 & 151 & 17.59 & 0.10 & 2.27 & 13.69 & 2.32 & 2.13 & 0.32 & 6.26 & 0.79 & 1.43 \\
\hline & Budscales & 110 & 54 & 2.19 & 0.02 & 0.19 & 0.99 & 0.21 & 0.09 & 0.03 & 0.26 & 0.13 & 0.10 \\
\hline & Misc. & 49 & 24 & 1.01 & 0.02 & 0.15 & 0.46 & 0.12 & 0.05 & 0.21 & 0.59 & 0.08 & 0.10 \\
\hline \multirow{4}{*}{$\begin{array}{l}\text { Dec. 66- } \\
\text { March } 67\end{array}$} & Twigs & 465 & 228 & 5.07 & 0.09 & 0.46 & 3.15 & 0.29 & 0.20 & 0.14 & 2.41 & 0.21 & 0.56 \\
\hline & Leaves & 1048 & 514 & 14.29 & 0.27 & 0.66 & 9.46 & 0.74 & 0.58 & 0.58 & 6.37 & 0.61 & 1.65 \\
\hline & Budscales & 0 & - & - & - & - & - & - & - & - & - & - & - \\
\hline & Misc. & 38 & 19 & 0.87 & 0.01 & 0.05 & 0.28 & 0.03 & 0.02 & 0.06 & 0.56 & 0.05 & 0.09 \\
\hline \multirow{4}{*}{ Total } & Twigs & 1035 & 508 & 12.16 & 0.23 & 1.27 & 7.74 & 0.84 & 0.58 & 0.30 & 3.60 & 0.54 & 1.08 \\
\hline & Leaves & 2840 & 1375 & 38.66 & 0.46 & 3.90 & 25.48 & 3.62 & 3.04 & 0.95 & 13.37 & 1.70 & 3.42 \\
\hline & Budscales & 624 & 306 & 12.42 & 0.09 & 1.50 & 5.61 & 1.20 & 0.52 & 0.15 & 1.47 & 0.73 & 0.55 \\
\hline & Misc. & 269 & 172 & 6.07 & 0.08 & 0.53 & 2.59 & 170 & 0.24 & 0.32 & 2.87 & 0.41 & 0.37 \\
\hline Total litterfall (L) & & 4768 & 2321 & 69.31 & 0.86 & 7.20 & 41.42 & 7.36 & 4.38 & 1.72 & 2.31 & 3.38 & 5.42 \\
\hline Surface litter (SL) & & 6010 & 2825 & 107 & 0.75 & 6.63 & 58.92 & 8.65 & 7.30 & 3.43 & 128.07 & 4.47 & 13.86 \\
\hline Finer fractions & & 4400 & 1985 & 99 & 0.60 & 5.00 & 44.92 & 7.39 & 6.29 & 2.77 & 118.20 & 3.87 & 12.07 \\
\hline Branches & & 1670 & 840 & 7.8 & 0.15 & 1.63 & 14.00 & 1.29 & 1.01 & 0.66 & 9.87 & 0.60 & 1.79 \\
\hline $\begin{array}{l}\text { TOTAL LITTER } \\
\quad(\mathrm{L}+\mathrm{SL})\end{array}$ & & 10,778 & 5146 & 176.3 & 1.61 & 13.83 & 100.34 & 16.04 & 11.68 & 5.15 & 149.38 & 7.85 & 19.28 \\
\hline k-value & & 0.44 & 0.45 & 0.39 & 0.53 & 0.52 & 0.41 & 0.46 & 0.38 & 0.20 & 0.14 & 0.43 & 0.28 \\
\hline
\end{tabular}

or absorbed elements (negative values) in the canopy. The Diff value also included possible dry deposited aerosols (A). What were possibly overlooked were elements from A that had been absorbed into the leaves. This can be the case e.g. for $\mathrm{NO}_{3}$ and $\mathrm{NH}_{4}$ ions.

The amount of precipitation in the year of measurement (1967) was $644 \mathrm{~mm}$. The amount captured by the canopy, interception, was $168 \mathrm{~mm}$. The input of elements with rain was in decreasing order: $\mathrm{Cl}, \mathrm{S}, \mathrm{N}, \mathrm{Na}, \mathrm{Ca}$, $\mathrm{Mg}, \mathrm{K}, \mathrm{Mn}$ and $\mathrm{P}$ in amounts ranging from 23 to $0.04 \mathrm{~kg} \cdot \mathrm{ha}^{-1} \cdot \mathrm{yr}^{-1}$. The through fall contained in decreasing order: $\mathrm{Cl}, \mathrm{K}, \mathrm{S}, \mathrm{N}, \mathrm{Na}, \mathrm{Ca}, \mathrm{Mg}, \mathrm{Mn}$ and $\mathrm{P}$, in amounts ranging from 55 to $1.5 \mathrm{~kg} \cdot \mathrm{ha}^{-1} \cdot \mathrm{yr}^{-1}$. The higher values show the most readily motile elements.

Special consideration needs to be given to deposition of sulfur and nitrogen. The open field received inputs of $11.0 \mathrm{~kg} \mathrm{~S} \mathrm{ha}{ }^{-1} \cdot \mathrm{yr}^{-1}$ and $9.4 \mathrm{~kg} \mathrm{~N} \mathrm{ha}{ }^{-1} \cdot \mathrm{yr}^{-1}$. The through fall contained $34.3 \mathrm{~S}$ and $22.3 \mathrm{~N} \mathrm{~kg} \cdot \mathrm{ha}^{-1} \cdot \mathrm{yr}^{-1}$. Over time, these amounts would contribute to acidification of the soil and one-sided fertilisation of the forest. The study area was located in a rural landscape not far from urban areas, which may explain the very high level of S, but also the unexpectedly high level of N. The levels observed were lower than those reported for the north-west of the region at the time (Nihlgård 1972). Since then, S deposition has strongly decreased and the Slevel in the open field today is approx. $5 \mathrm{~kg} \cdot \mathrm{ha}^{-1} \cdot \mathrm{yr}^{-1}$. The present day $\mathrm{N}$ deposition rate is approximately $10 \mathrm{~kg} \cdot \mathrm{ha}^{-1} \cdot \mathrm{yr}^{-1}$ (Pihl-Karlsson et al. 2012).

\subsection{Soil Organic Matter and Exchangeable Mineral Content}

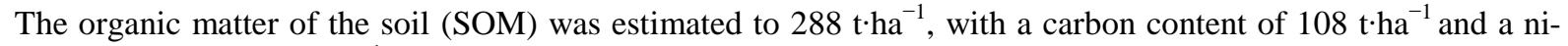
trogen content of $12 \mathrm{t} \cdot \mathrm{ha}^{-1}$ (Table 7). The exchangeable (Exch) amounts in an extraction with ammonium acetate (Am-Ac) were in decreasing order: $\mathrm{Ca}, \mathrm{P}, \mathrm{Mg}, \mathrm{K}, \mathrm{Na}$ and $\mathrm{Mn}$. 
Table 6. Content of elements $\left(\mathrm{kg} \cdot \mathrm{ha}{ }^{-1}\right)$ in incoming precipitation $(\mathrm{In})$, throughfall $(\mathrm{T})$ and interception $($ Diff $=$ canopyleached fraction) in a mixed forest of Quercus robur and Corulys avellana in Linnebjer, Sweden.

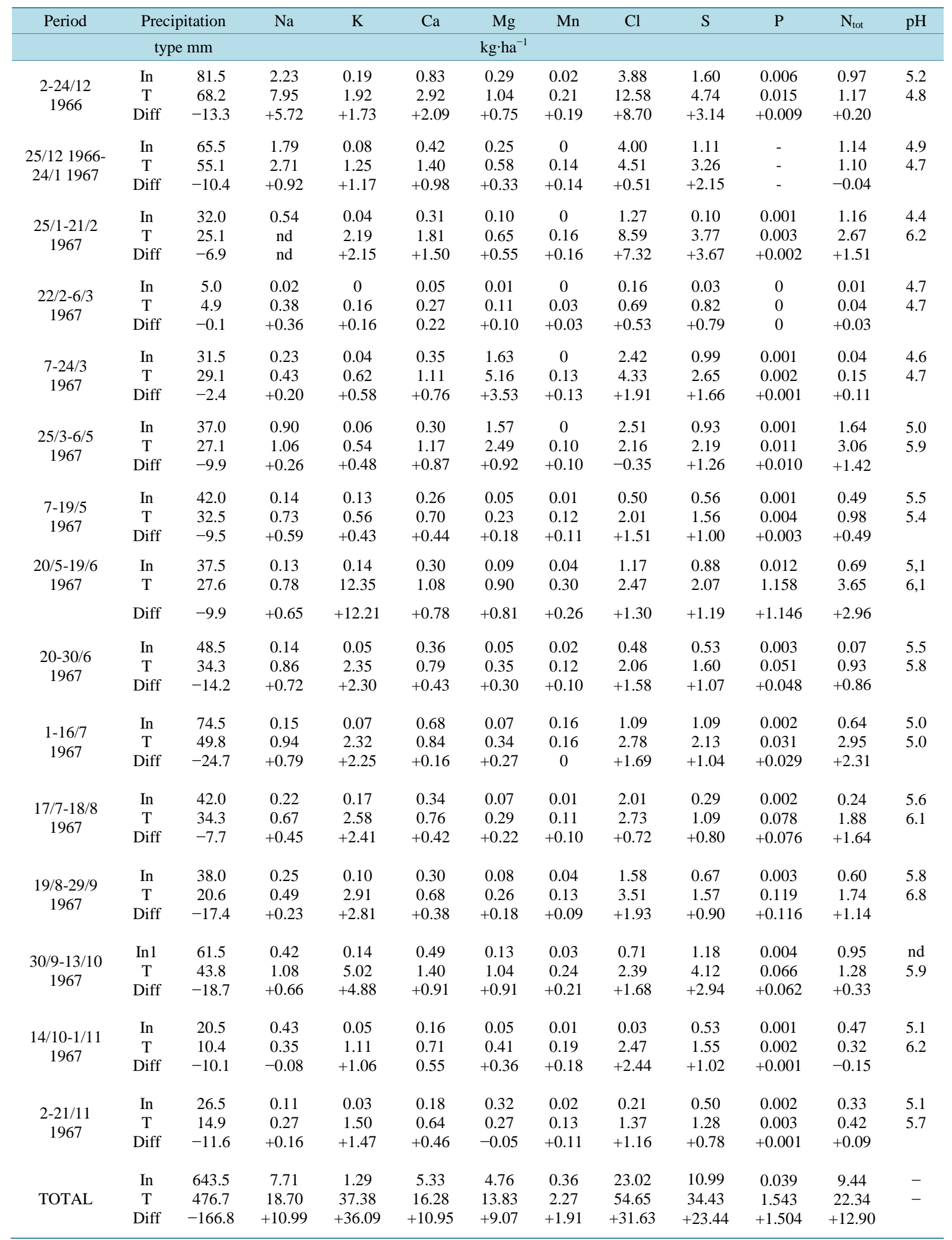

1) Estimated; nd = not determined. 


\section{Discussion}

Element cycling is currently a central theme in ecosystem ecology (Ågren \& Andersson 2012, Andersson 1970a). The main results of the present study are summarised in Table 8 . The yearly biomass increase indicates that at the time of measurement, the Linnebjer forest ecosystem is still in an aggradation or accumulation phase (Bormann \& Likens 1979). Tree biomass increased yearly by $6.6 \mathrm{t} \cdot \mathrm{ha}^{-1}$ or $3.1 \mathrm{t} \cdot \mathrm{ha}^{-1}$ carbon. The other elements accumulated in the order: $\mathrm{N}>\mathrm{Ca}>\mathrm{Mg}>\mathrm{K}>\mathrm{Mn}>\mathrm{Si}>\mathrm{P}$, in amounts ranging from 29 to $1.8 \mathrm{~kg} \cdot \mathrm{ha}^{-1}$ yearly. The litterfall returned elements to the soil. $14 \%$ - 53\% was decomposed and returned to the ecosystem over the year. It can thus be assumed that the exchangeable pool of elements was slightly increasing. The atmospheric deposition of sulfur observed was sufficient to cause acidification of the forest soil. The nitrogen input should have had a fertilising effect, leading to increased forest growth.

The results reported deal with plant biomass, primary production and mineral cycling. Earlier the two first properties have been reported, but the mineral cycling not. As the results still are valid and can serve as reference material, it is considered essential to have them published. The cycling of carbon, nitrogen and sulfur are elements, which are affected by a changing climate and deposition. Repeated investigations make it possible to address questions like the forest as a source or sink for carbon.

The result of plant biomass and production are less affected by time as the methods are considered as more or less the same today. Chemical methods and techniques have changed more. The results related to chemistry and reported are, however, considered as "robust" and will allow being used for comparisons. Even if "modern" chemical methods are used, the final results are depending on the quality of the data from the estimation of plant biomass and production.

In a follow up paper, results from an investigation of sampling in vegetation and soil after fifty years will be reported.

\section{Acknowledgements}

These investigations were carried out at the former Department of Ecology, University of Lund, under the leadership of Professor Nils Malmer. The work took place over a long period leading to a PhD degree in 1970. Mineral cycling of the oak forest was intended to be a part of the PhD thesis, but the analysis had to be postponed for practical reasons. A number of people assisted in the work. Laboratory assistance was provided by, among others, Anita Balogh, Maj-Lis Gernersson and Mimmi Varga. Field assistance was provided by a ne-

Table 7. Distribution of elements in soil organic matter (SOM) and amount in an extraction with ammonium acetate (AmAc.Exch) in the soil profile of a mixed forest of Quercus robur and Corylus avellana in Linnebjer, Sweden.

\begin{tabular}{|c|c|c|c|c|c|c|c|c|c|c|}
\hline Fraction & Organic matter & $\mathrm{C}$ & $\mathrm{N}$ & $\mathrm{C} / \mathrm{N}$ & $\mathrm{Na}$ & $\mathrm{K}$ & $\mathrm{Ca}$ & $\mathrm{Mg}$ & Mn & $\mathrm{P}$ \\
\hline & \multicolumn{3}{|c|}{$\mathrm{t} \cdot h \mathrm{a}^{-1}$} & ratio & \multicolumn{6}{|c|}{$\mathrm{kg} \cdot \mathrm{ha}^{-1}$} \\
\hline Soil organic matter $0-60 \mathrm{~cm}$ & 288 & 108 & 12.0 & 9 & - & - & - & - & - & - \\
\hline Am-Ac. Exch 0 - 40 cm & - & - & - & - & 221 & 226 & 532 & 242 & 55 & 256 \\
\hline
\end{tabular}

Table 8. Distribution of organic matter and chemical elements in some important above-ground functional fractions and turnover characteristics of a mixed forest of Quercus robur and Corylus avellana in Linnebjer, Sweden.

\begin{tabular}{|c|c|c|c|c|c|c|c|c|c|c|c|c|c|}
\hline Symbol & Fraction & Biomass & $\mathrm{C}$ & $\mathrm{N}$ & $\mathrm{C} / \mathrm{N}$ & $\mathrm{Na}$ & $\mathrm{K}$ & $\mathrm{Ca}$ & $\mathrm{Mg}$ & $\mathrm{Fe}$ & $\mathrm{Mn}$ & $\mathrm{P}$ & Si \\
\hline & & \multicolumn{3}{|c|}{$\mathrm{t} \cdot \mathrm{ha}^{-1}$} & ratio & \multicolumn{8}{|c|}{$\mathrm{kg} \cdot \mathrm{ha}^{-1}$} \\
\hline PP & Yearly primary production & 12.8 & 6.33 & 0.165 & 38 & 1.17 & 49.4 & 66.8 & 24.1 & 1.51 & 13.6 & 9.6 & 27.3 \\
\hline$\Delta \mathrm{B}$ & Yearly biomass increase & 6.6 & 3.06 & 0.029 & 106 & 0.26 & 8.9 & 20.3 & 14.0 & 0.42 & 8.3 & 1.8 & 2.8 \\
\hline $\mathrm{L}$ & Yearly litterfall & 4.8 & 2.32 & 0.070 & 33 & 0.86 & 7.2 & 41.4 & 7.4 & 1.72 & 4.4 & 3.8 & 21.3 \\
\hline CL & Canopy leached fraction & - & - & 0.013 & - & 10.99 & 36.1 & 11.0 & 9.1 & - & 1.4 & 1.5 & - \\
\hline $\mathrm{R}$ & Input by rain & - & - & 0.009 & - & 7.71 & 1.3 & 5.3 & 4.8 & - & 0.4 & $<0.1$ & - \\
\hline SL & Surface litter & 6.1 & 2.83 & 0.110 & 26 & 0.75 & 6.6 & 58.9 & 8.7 & 3.43 & 7.3 & 4.5 & 128 \\
\hline SOM & Soil organic matter & 288 & 108 & 12 & 9 & - & - & - & - & - & - & - & - \\
\hline \multirow[t]{4}{*}{ Exch } & Exch. in soil & - & - & - & - & 221 & 226 & 532 & 242 & - & 55 & 421 & - \\
\hline & $P P-\Delta B$ & 6.2 & 3.27 & 0.136 & - & 0.91 & 40.4 & 46.5 & 10.8 & 1.09 & 5.3 & 7.5 & 24.6 \\
\hline & $\mathrm{L}+\mathrm{CL}$ & - & - & 0.11 & - & 11.74 & 43.3 & 54.4 & 16.4 & - & 6.3 & 5.3 & - \\
\hline & $\mathrm{L} / \mathrm{L}+\mathrm{SL}$ & 0.44 & 0.45 & 0.39 & - & 0.53 & 0.52 & 0.41 & 0.46 & 0.33 & 0.38 & 0.46 & 0.14 \\
\hline
\end{tabular}


ver-failing study mate, Jan Ericsson, and staff at the Botanical Garden, Lund. Many measurements and samplings were performed by a local farmer.

The scientific work involved intense collaboration and exchanges over the years with Professor emeritus Bengt Nihlgård, Lund, who shared the final work. Scientifically, I am also indebted to Professor emeritus Göran Ågren, Uppsala, whose collaboration was an essential factor in finalising this work.

The Swedish Natural Science Research Council provided the main funding for the research.

\section{References}

Ågren, G. I., \& Andersson, F. O. (2012). Terrestrial Ecosystem Science-Principles and Applications (pp. 230). Cambridge: Cambridge University Press.

Andersson, F. (1970a). An Ecosystem Approach to Vegetation, Environment and Organic Matter of a Mixed Woodland and Meadow Area. Thesis, Lund.

Andersson, F. (1970b). Ecological Studies in a Scanian Woodland and Meadow Area, Southern Sweden. I. Vegetational and Environmental Structure. Opera Botanica, 27, 190.

Andersson, F. (1970c). Ecological Studies in a Scanian Woodland and Meadow Area, Southern Sweden. II Plant Biomass, Primary Production and Turnover of Organic Matter. Botaniska Notiser, 123, 8-51.

Barrett, R. H., \& Brodin, G. (1955). The Acidity of Scandinavian Precipitation. Tellus, 7, 251-257. http://dx.doi.org/10.1111/j.2153-3490.1955.tb01159.x

Bormann, F. H., \& Likens, G. E. (1979). Pattern and Processes in a Forested Ecosystem (pp. 253). New York: Springer Verlag. http://dx.doi.org/10.1007/978-1-4612-6232-9

Bray, R. H. (1945). Nitrate Tests for Soil and Plant Tissues. Soil Science, 60, 219-221. http://dx.doi.org/10.1097/00010694-194509000-00003

Chesnin, L., \& Yien, C. H. (1950). Turbidimetric Determination of Available Sulphates. Soil Science Society of America Journal, 15, 149-151. http://dx.doi.org/10.2136/sssaj1951.036159950015000C0032x

Clarke, F. E. (1950). Determination of Chloride in Water. Analytical Chemistry, 22, 553-555. http://dx.doi.org/10.1021/ac60040a011

Karlgren, L. (1962). Vattenkemiska Analysmetoder. Limn. Inst. Uppsala. Mimeographed, 115.

Murphy, J., \& Riley, J. P. (1962). A Modified Single Solution Method for Determination of Phosphates in Natural Waters. Analytica Chimica Acta, 27, 31-35. http://dx.doi.org/10.1016/S0003-2670(00)88444-5

Nihlgård, B. (1970). Precipitation, Its Chemical Composition and Effect on Soil Water in a Beech and a Spruce Forest in South Sweden. Oikos, 21, 208-217. http://dx.doi.org/10.2307/3543676

Nihlgård, B. (1972). Plant Biomass, Primary Production and Distribution of Chemical Elements in a Beech and a Planted Spruce Forest in South Sweden. Oikos, 23, 68-91. http://dx.doi.org/10.2307/3543928

Nihlgård, B., \& Lindgren, L. (1977). Plant Biomass, Primary Production and Bioelements of Three Mature Beech Forests in South Sweden. Oikos, 28, 95-104. http://dx.doi.org/10.2307/3543328

Pihl-Karlsson, G., Akselsson, G., Hellsten, S., Kronnäs, V., \& Karlsson, P. E. (2012). The State of the Forest Environment in Scania. Report B 205, Gothenburg: The Swedish Environment Institute, IVL, 33 p. (In Swedish)

Reichle, D. E. (1981). Dynamic Properties of Forest Ecosystems. International Biological Programme 23. Cambridge: Cambridge University Press.

Rossum, J. R., \& Villarez, P. A. (1961). Suggested Method for Turbidimetric Determination of Sulfate in Water. American Water Work Association, 53, 873-876.

SMHI (1958). Handbook for Weather Observers. Meteorological and Hydrological Institute. Stockholm. (In Swedish) 
Scientific Research Publishing (SCIRP) is one of the largest Open Access journal publishers. It is currently publishing more than 200 open access, online, peer-reviewed journals covering a wide range of academic disciplines. SCIRP serves the worldwide academic communities and contributes to the progress and application of science with its publication.

Other selected journals from SCIRP are listed as below. Submit your manuscript to us via either submit@scirp.org or Online Submission Portal.
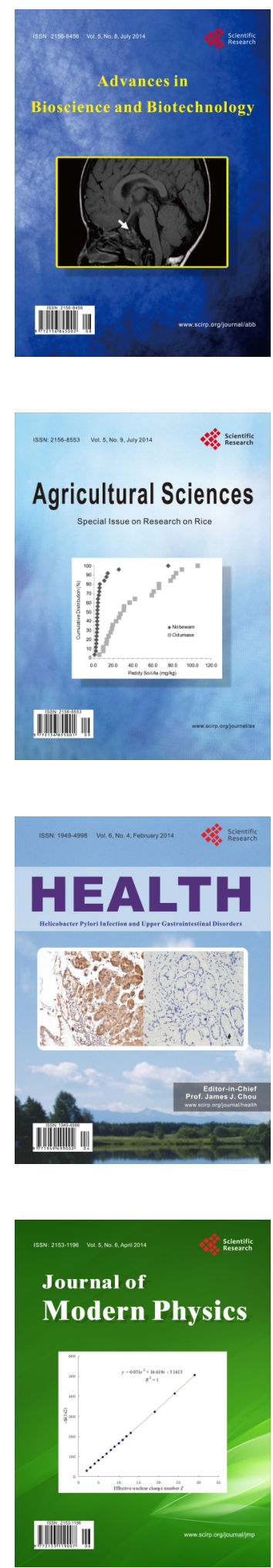
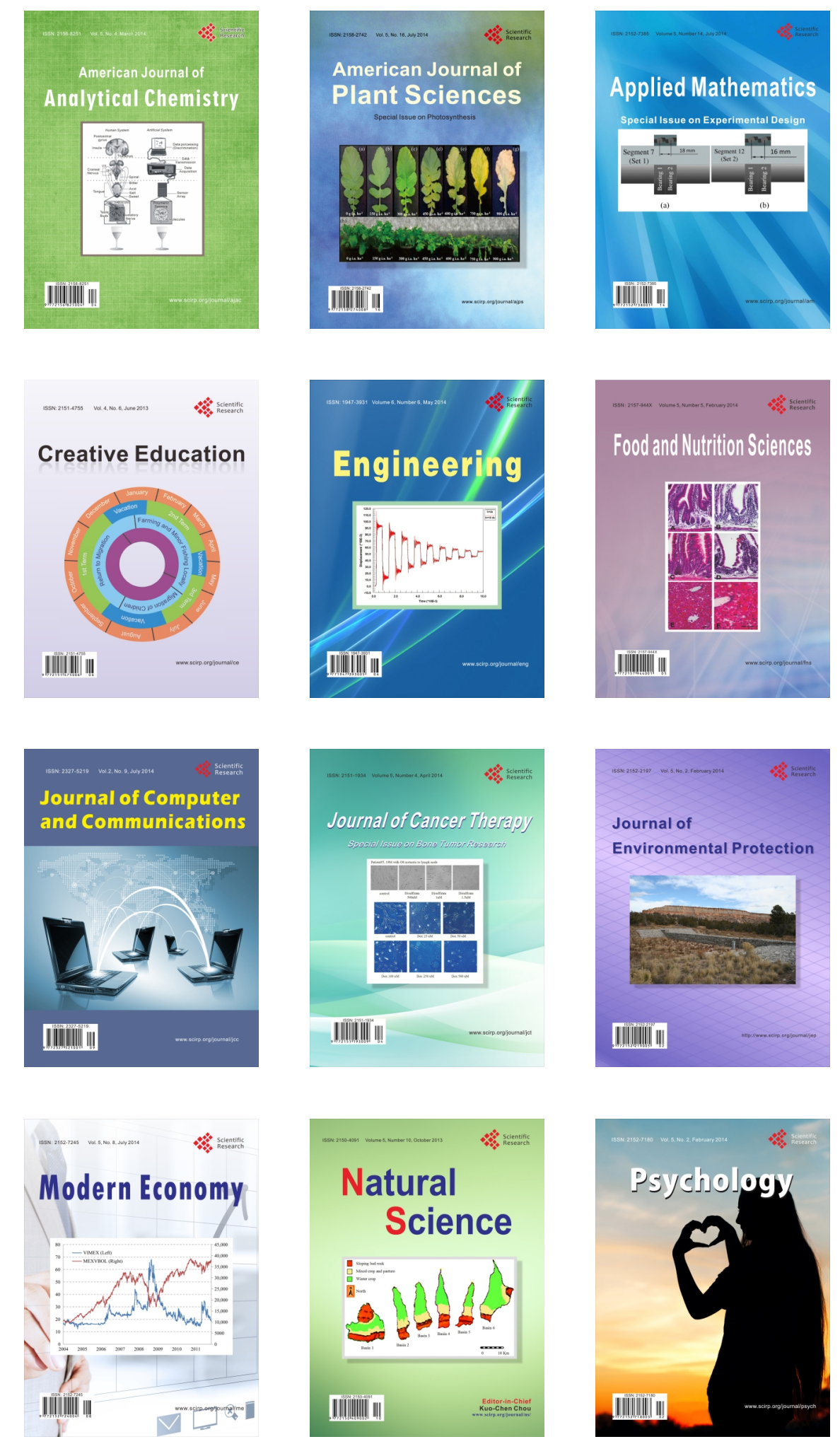